\title{
Sistem Pendeteksi Kepatahan Mata Bor Pada Mesin Cetak PCB Berdasarkan Analisa Getaran Spindle Menggunakan Teensy Board
}

\author{
Putra Trimardian Asri, Muhammad Rivai, Tasripan \\ Departemen Teknik Elektro, Fakultas Teknologi Elektro, Institut Teknologi Sepuluh Nopember \\ E-mail:muhammad_rivai@ee.its.ac.id
}

\begin{abstract}
Abstrak-Pemanfaatan Computer Numerical Control (CNC) adalah salah satu bentuk penerapan teknologi industri yang membuat hasil produksi lebih presisi dan akurat. CNC juga dapat diterapkan pada proses pencetakan Printed Circuit Board (PCB) menggantikan proses pelarutan secara kimiawi yang tidak ramah lingkungan. Akan tetapi penggunaan pencetak PCB berbasis CNC memiliki risiko yakni patahnya mata bor. Pada penelitian ini telah dibuat suatu sistem pendeteksian kepatahan mata bor berdasarkan analisa getaran. Sensor yang digunakan untuk dapat mendeteksi getaran adalah MEMS accelerometer yang mempunyai kemampuan pengukuran sampai 3,6g. Untuk dapat mengenali kepatahan mata bor, perlu dilakukan pengolahan sinyal dengan menggunakan Fast Fourier Transform. Lebar spektrum frekuensi yang digunakan adalah $0-1000 H z$. Pola spektrum frekuensi tersebut digunakan sebagai input Artificial Neural Network untuk dapat mengenali kepatahan mata bor. Pemrosesan Fast Fourier Transform dan Artificial Neural Network dilakukan pada Teensy 3.2 development board. Hasil eksperimen dengan kecepatan putaran spindle 30000 RPM menunjukkan bahwa Artificial Neural Network dapat mendeteksi kepatahan mata bor dengan tingkat keberhasilan 80\%. Penggunaan jenis PCB yang lebih keras dapat meningkatkan keberhasilan menjadi $91.67 \%$. Sistim ini diharapkan dapat diterapkan pada CNC sebagai pencetak PCB sehingga dapat lebih efisien pada konsumsi daya dan waktu.
\end{abstract}

Kata Kunci-Artificial Neural Network, Fast Fourier Transform, Kepatahan Mata Bor, Pencetak PCB.

\section{PENDAHULUAN}

$\mathrm{P}$ ENGGUNAAN alat produksi otomatis seperti CNC membawa perkembangan yang baik dalam kualitas dan produktivitas pabrik. Penggunaan mesin CNC membuat hasil produksi lebih presisi dan akurat sehingga dapat memenuhi keinginan konsumen. Namun pengoperasian mesin CNC dalam kurun waktu tertentu akan menimbulkan perubahan dalam mesin tersebut karena pengaruh faktor eksternal[1]. Untuk itu dalam bidang industri, pemantauan proses produksi dan kesalahan yang timbul adalah hal yang penting untuk dilakukan.

Penggunaan $\mathrm{CNC}$ untuk memproses material keras dapat menimbulkan kerusakan pada mata bor. Tidak terdapatnya pendeteksi kerusakan mata bor pada mesin CNC yang ada di pasaran membuat kerugian produksi semakin tinggi karena energi tetap diserap namun alat tidak bekerja sebagaimana mestinya sehingga energi tersebut akan terbuang percuma.

Pendeteksian kerusakan mata bor sebenarnya telah dipelajari dengan berbagai bentuk dan cara. Berdasar dari pengetahuan yang didapat dari penelitian pemantauan kondisi mata bor secara konvensional, pendeteksian tak langsung seperti daya, gaya pemotongan, getaran, dan sinyal emisi akustik adalah kandidat untuk dapat mendeteksi kondisi mata bor. Dengan mempertimbangkan murahnya harga MEMS accelerometer, sistem pendeteksi getaran pada spindle menawarkan keuntungan dari mudahnya pemasangan dan biaya yang efektif [2].

Masalah di atas melatarbelakangi penulis untuk melakukan penelitian ini. Diharapkan dari penelitian ini akan didapatkan suatu bentuk pendeteksi kepatahan mata bor yang efektif, murah, dan mudah dipasang sehingga dapat meningkatkan efisiensi, akurasi dan stabilitas mesin pencetak PCB.

\section{DASAR TEORI}

Pencetak PCB adalah suatu peranti untuk mencetak jalur sirkuit pada media berlapis tembaga untuk selanjutnya dapat dipasangi komponen elektronik. Jalur ini akan digores dan diberi lubang untuk komponen dengan menggunakan mesin Computer Numerical Control (CNC) [3]. Cara lain untuk melakukan proses pencetakan $\mathrm{PCB}$ adalah dengan proses kimia, yakni dengan $\mathrm{FeCl}_{3}$ pada proses etching [4]. Akan tetapi penggunaan $\mathrm{FeCl}_{3}$ sebagai zat kimia pelarut dapat menyebabkan risiko yang tinggi terhadap kesehatan [5].

Pada CNC terdapat sebuah spindle yang merupakan bagian berputar yang dilengkapi dengan mata bor berperan untuk memberi lubang, routing, milling, dan sebagainya. Getaran spindle ini akan dianalisa dan diharapkan dapat diketahui jika mata bor yang digunakan patah.

Getaran adalah gerakan osilasi pada sistem mekanik terhadap titik keseimbangan [6]. Ilustrasi getaran dapat digambarkan sebagai sebuah gerak bebas dari per (spring) ditunjukkan pada Gambar 1. Persamaan untuk gerak bebas sebuah pegas adalah $F s=-k \cdot x$. Di mana persamaan $x$ dapat dituliskan sebagai :

$$
\begin{aligned}
& X(t)=A \sin (2 \pi \cdot f n \cdot t) \\
& X(t)=A \sin (\omega t) \\
& f n=\frac{1}{2 \pi} \sqrt{\frac{k}{m}}
\end{aligned}
$$

Persamaan 1 merupakan persamaan perpindahan getaran secara umum. Jika persamaan tersebut diturunkan maka akan didapat persamaan kecepatan dan percepatan getaran, dinyatakan sebagai: 


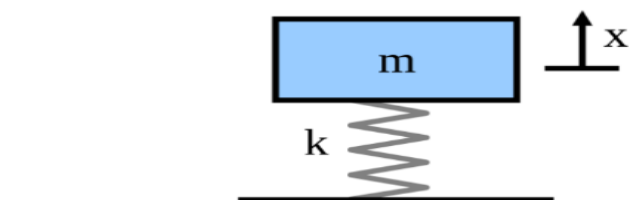

Gambar 1. Ilustrasi getaran pegas

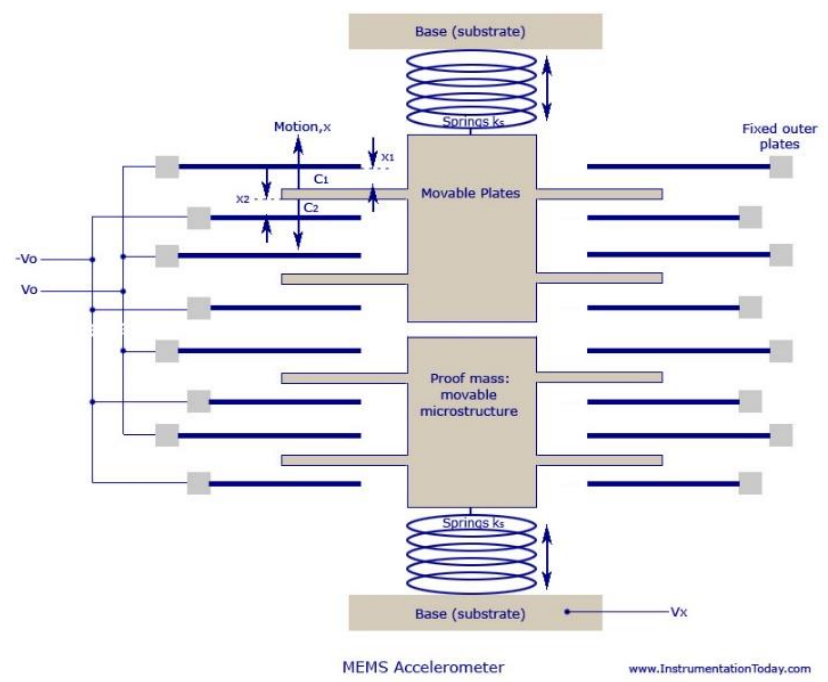

Gambar 2. Struktur MEMS Accelerometer [7]

$$
\begin{aligned}
& v=\frac{d x}{d t}=\omega A \cos (\omega t) \\
& a=\frac{d^{2} x}{d t}=-\omega^{2} A \sin (\omega t) \\
& a=-\frac{k x_{1}^{2}}{2 m \epsilon} \Delta C
\end{aligned}
$$

Accelerometer Micro-Electro Mechanical Sensor (MEMS) menggunakan prinsip kerja percepatan (acceleration). Beban bergerak dengan suatu percepatan sampai kondisi tertentu akan berhenti. Bila ada sesuatu yang mengguncangnya maka beban akan berayun kembali. Konsep ini diterapkan pada sebuah chip kecil, dimana pegas dibuat dengan pelat mini yang ujungnya diberi penyangga dan di tengahnya diberi beban. Pelat dipasang dalam posisi berhadapan. Saat ada gaya dari luar maka pelat beban akan bergerak mendekat pelat tetap. Bila pelat sebagai kapasitor maka besaran kapasitansi akan berubah. Hubungan antara kapasitansi dan percepatan ditunjukkan persamaan 6 . Ilustrasi accelerometer MEMS ditunjukkan pada Gambar 2. Agar sensor ini bisa mendeteksi 3 dimensi, maka dibutuhkan 3 pasang pelat yang dipasang tegak lurus antar masingmasing.

Analisa menggunakan transformasi fourier adalah suatu bentuk penguraian sinyal berdasar sinusoidal penyusunnya [8][7]. Untuk dapat diaplikasikan pada sinyal digital, pendekatan yang digunakan adalah Discrete Fourier Transform (DFT) yang dinyatakan oleh persamaan 8 untuk menyelesaikan perhitungan.

$$
\begin{aligned}
& X(f)=\int_{\infty}^{\infty} x(t) \cdot e^{-j \omega t} d t \\
& X[n]=\sum_{k=0}^{N-1} x(k) \cdot e^{-\frac{j w n k}{N}}
\end{aligned}
$$

Fast Fourier Transform (FFT) adalah algoritma untuk mengaplikasikan DFT secara efisien. Sinyal vibrasi yang diukur oleh transduser masih sebagai fungsi waktu.
Persamaan dasar Fast Fourier Transform adalah sebagai berikut :

$$
\begin{aligned}
& X(k)=\sum_{N=0}^{N-1} x(n) W_{N}^{k n} \\
& \text { dengan } n, k, N \text { adalah integer, } k=0,1,2,3, \cdots, N-1 \\
& \text { dan } j=\sqrt{-1} \\
& W_{N}=e^{-j 2 \pi / N}=\operatorname{Cos} \frac{2 \pi}{N}-j \operatorname{Sin} \frac{2 \pi}{N}
\end{aligned}
$$

Karena $x(n)=x_{r}(n)+j_{x I}(n)$ bisa bernilai kompleks, maka $x(k)=x_{R}(k)+j X_{I}(k)$ yaitu :

$X_{R}(k)=\sum_{N=0}^{N-1}\left[X r(n) \operatorname{Cos} 2 \pi \frac{k}{N} n+X_{I}(n) \sin 2 \pi \frac{k}{N} n\right]$
$X_{I}(k)=\sum_{N=0}^{N-1}\left[X R(n) \operatorname{Cos} 2 \pi \frac{k}{N} n+X_{I}(n) \sin 2 \pi \frac{k}{N} n\right]$

Dari persamaan tersebut dapat dilihat memerlukan $2 N^{2}$ evaluasi fungsi trigonometri ditambah $4 N^{2}$ perkalian real ditambah $4 N(N-1)$ penjumlahan real dan sejumlah indexing dan addressing operators. Persamaan ini merupakan bentuk transformasi fourier yang siap dihitung secara langsung dari bentuk sinyal $\mathrm{x}(\mathrm{t})$.

Artificial Neural Network (ANN) adalah bentuk pemodelan komputer dari sistem saraf manusia. Metode ini menggunakan elemen perhitungan non-linier dasar yang disebut neuron yang diorganisasikan sebagai jaringan yang saling berhubungan sehingga mirip dengan jaringan saraf manusia. Jaringan saraf tiruan dibentuk untuk memecahkan suatu masalah tertentu seperti pengenalan pola atau klasifikasi karena proses pembelajaran.

Setiap pola-pola informasi input dan output yang diberikan ke dalam ANN diproses dalam neuron. Neuron-neuron tersebut terkumpul di dalam lapisan yang disebut neuron layer. Lapisan penyusun ANN tersebut dapat dibagi menjadi 3, yaitu:

\section{1) Lapisan input}

Unit-unit di dalam lapisan input disebut unit input. Unitunit input tersebut menerima pola input data dari luar yang menggambarkan suatu permasalahan.

2) Lapisan tersembunyi

Unit di dalam lapisan tersembunyi disebut unit tersembunyi dimana output-nya tidak dapat secara langsung diamati.

3) Lapisan output

Unit di dalam lapisan tersembunyi disebut unit output. Output dari lapisan ini merupakan solusi ANN terhadap suatu permasalahan.

\section{PERANCANGAN SISTEM}

Perancangan perangkat keras terdiri dari tiga bagian yaitu pembacaan sensor, pengendalian spindle, dan pengiriman data ke PC. Keseluruhan sistem dikendalikan dan diproses oleh Teensy 3.2. Proses pembacaan data dilakukan oleh sensor accelerometer ADXL335 untuk membaca getaran dari spindle. Pengendalian spindle dilakukan oleh Solid State Relay untuk menyalakan atau mematikan spindle. Komputer dalam penelitian ini digunakan sebagai antarmuka untuk menampilkan nilai hasil pengolahan pada Teensy 3.2 melalui komunikasi serial. 


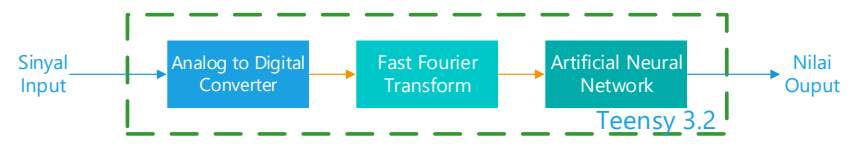

Gambar 3. Diagram blok pemrosesan pada Teensy 3.2

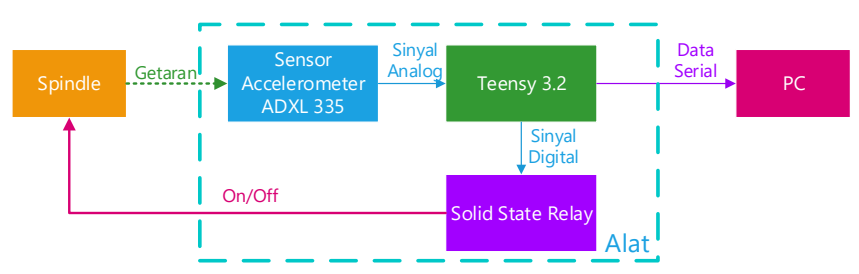

Gambar 4. Diagram blok sistem perangkat keras

Berdasarkan gambar 3, alur kerja dari sistem adalah dengan mengukur nilai getaran pada spindle menggunakan sensor accelerometer ADXL335. Pemasangan sensor accelerometer tersebut menempel permukaan spindle dan dekat dengan mata bor untuk dapat merasakan getaran spindle dengan baik. Kemudian sinyal analog dari sensor diolah pada Teensy 3.2 untuk menentukan status kerja spindle yang dikontrol menggunakan Solid State Relay (SSR). Data hasil pengolahan pada mikrokontroler Teensy 3.2 dikirimkan ke komputer.

Sistem pemrosesan pada sistim ini ditunjukkan pada gambar 4. Data pembacaan analog dari sensor accelerometer diubah ke nilai digital pada Analog to Digital Converter (ADC). ADC internal Teensy 3.2 memiliki resolusi 12-bit sehingga perubahan tegangan yang kecil dapat dibaca dengan baik. Konversi ini bertujuan untuk memudahkan pengolahan nilai lebih lanjut secara digital.

Hasil konversi nilai tegangan sensor diolah untuk dilakukan transformasi fourier yang dikerjakan oleh modul DSP internal Teensy 3.2. Pemrosesan pada DSP memungkinkan beban kerja pada prosesor Teensy 3.2 berkurang karena tidak perlu lagi melakukan komputasi persamaan Fast Fourier Transform yang rumit. Parameter FFT yang digunakan dalam penelitian ini meliputi FFT size sebesar 256, sample rate $2000 \mathrm{~Hz}$. Penggunaan parameter tersebut dapat diketahui bahwa setiap nilai magnitudo spektrum sinyal mewakili resolusi frekuensi $8 \mathrm{~Hz}$. Hal ini dapat dibuktikan dengan persamaan 13.

Resolusi Freq $=\frac{\text { Sample rate }}{\text { FFT size }}=\frac{2000}{256}=7,8125 \approx 8$

ANN pada penelitian ini digunakan sebagai pengidentifikasi getaran untuk menunjukkan apakah mata bor yang digunakan mengalami patah atau tidak. Teensy 3.2 hanya menjalankan propagasi maju saja dengan nilai bobot dan bias yang sudah diperoleh dari fasa pembelajaran. ANN yang digunakan menggunakan 2 hidden layer dan 1 layer output dengan konfigurasi Log Sigmoid - Log Sigmoid Linear seperti yang ditunjukkan gambar 5.

Proses pembelajaran ANN terlebih dahulu dilakukan untuk mendapatkan nilai Weight (bobot) dan Bias. Proses ini dilakukan menggunakan bantuan komputer dalam pengambilan data dan pembelajaran ANN. Proses pembelajaran menggunakan nilai target yang ditunjukkan pada tabel 1.

Sebelum diproses menggunakan Artificial Neural Network, data dari Fast Fourier Transform dinormalisasi dengan Persamaan 14. Algoritma untuk diterapkan pada sistem merupakan Feedforward Propagation seperti pada

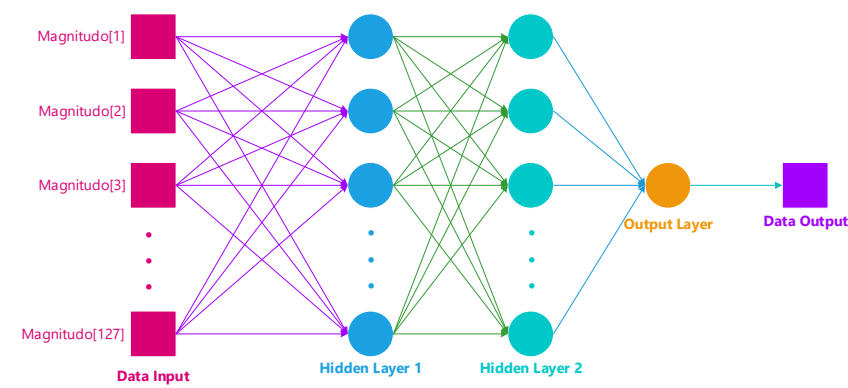

Gambar 5. Arsitektur Artificial Neural Network

Persamaan 15. Sedangkan untuk aktivasi log sigmoid menggunakan Persamaan 16.

Tabel 1.

Pola target dan nilai target dari Artificial Neural Network

Pola Target
Spindle tidak berputar
Spindle berputar dan tidak menggerus
Spindle berputar dan menggerus

\section{PENGUJIAN DAN ANALISIS}

\section{A. Pengujian Fast Fourier Transform}

Pengujian ini dilakukan dengan memberikan input ADC dengan sinyal dari function generator, ditunjukkan pada Gambar 6. Hasil pengujian ini menunjukkan kesesuaian FFT yang ditunjukkan pada gambar 7 .

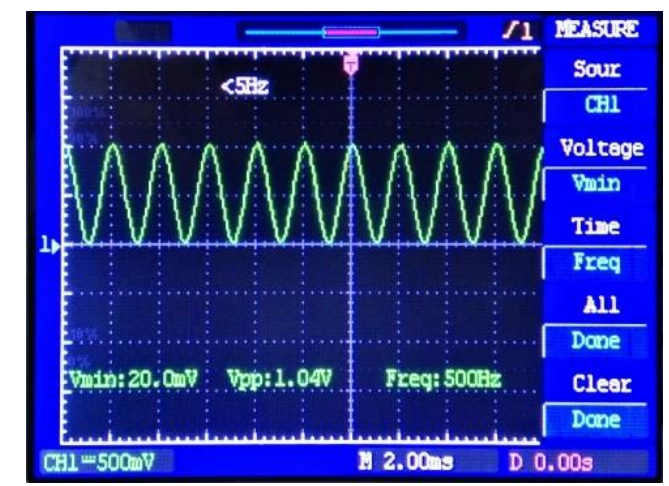

Gambar 6. Input sinyal sinusoidal $500 \mathrm{~Hz}$

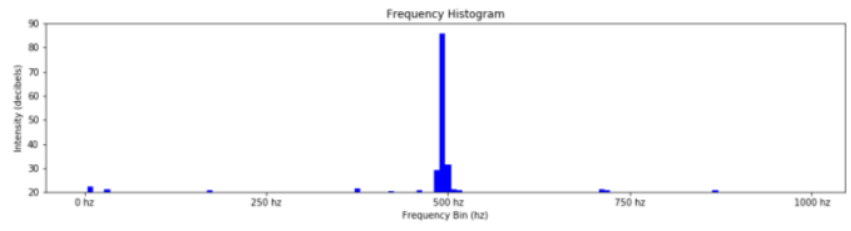

Gambar 7. Output FFT pada $500 \mathrm{~Hz}$ 


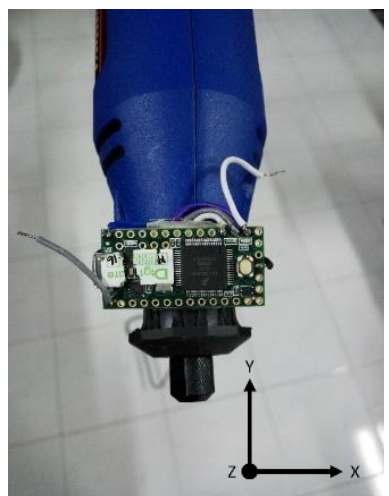

Gambar 8. Pemasangan ADXL335 dan Teensy 3.2 pada spindle

Pengujian dilanjutkan untuk mengetahui performa FFT jika diberi input sinyal dari sensor accelerometer. Hasil pengujian ini ditampilkan pada Gambar 9 hingga Gambar 12.

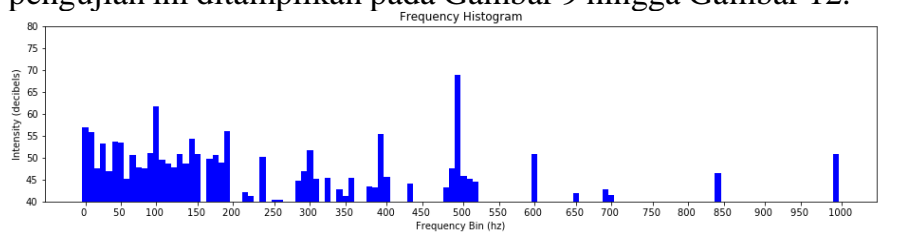

(a)

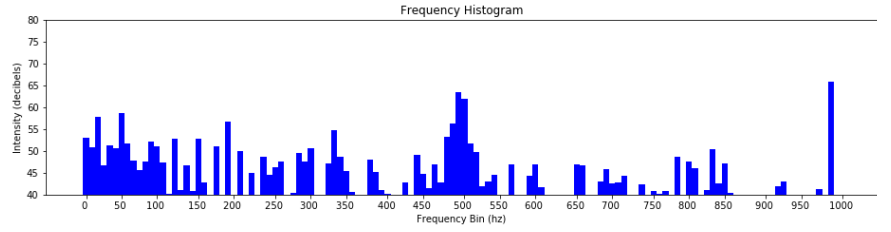

(b)

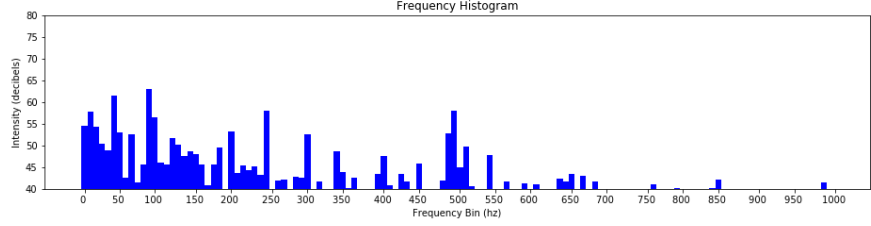

(c)

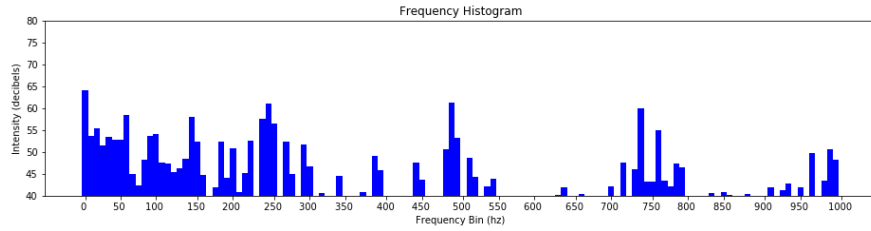

(d)

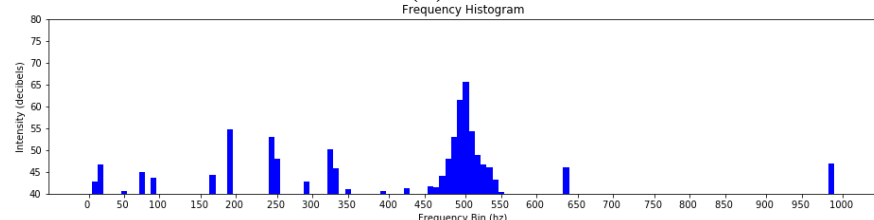

(e)

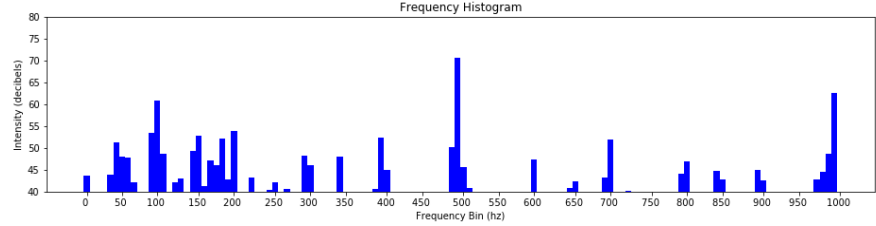

(f)

Gambar 9. Pengujian FFT dengan sensor pada (a) X-axis tanpa menggores, (b) $\mathrm{X}$-axis dengan menggores, (c) Y-axis tanpa menggores, (d) Y-axis dengan menggores, (e) Z-axis tanpa menggores, (f) Z-axis dengan menggores

Hasil ini menunjukkan pembacaan sensor yang baik ditinjau dari magnitudo untuk spektrum dominan cukup tinggi dan adanya perbedaan yang berarti antara kondisi menggerus atau tidak. Jika dibandingkan dengan sumbu $\mathrm{X}$, sumbu $\mathrm{Z}$ memiliki hasil perbedaan spektrum frekuensi yang lebih signifikan. Hal tersebut berhubungan dengan arah getaran pada spindle yang bergerak secara sentrifugal.

\section{B. Pengujian Artificial Neural Network}

Proses learning atau pembelajaran ANN dilakukan di di komputer untuk mempercepat proses. Pada proses pembelajaran ini nilai error diset sebesar $10^{-5}$. Hasil verifikasi yang diperoleh pada tahap ini ditunjukkan pada Gambar 10. Hasil pengujian ini menunjukkan bahwa selisih antara target dan hasil pembelajaran Artificial Neural Network sangat kecil yaitu $6.25 \times 10^{-6}$ sehingga tercapai nilai target.

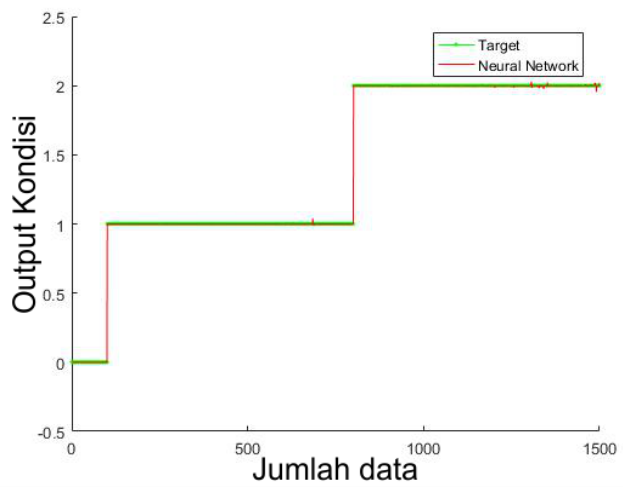

Gambar 10. Hasil Proses Learning ANN

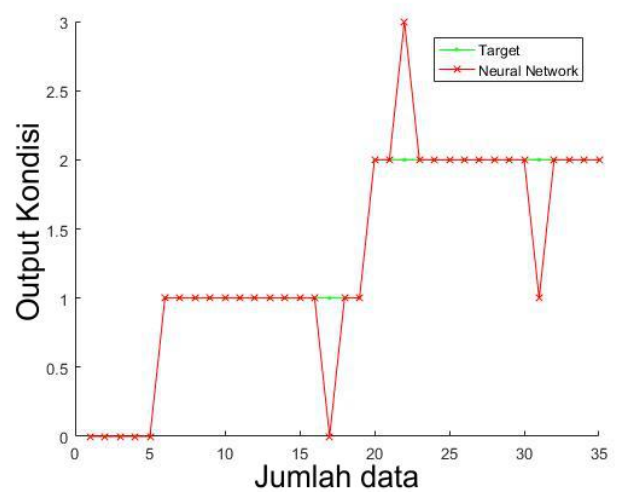

Gambar 11. Grafik pengujian ANN secara offline

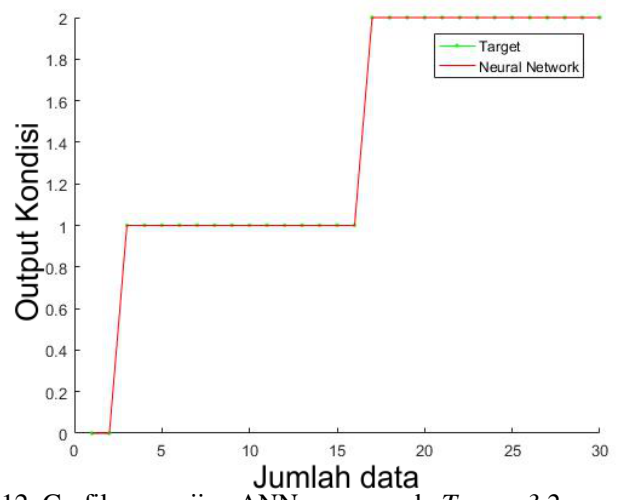

Gambar 12. Grafik pengujian ANN secara pada Teensy 3.2 


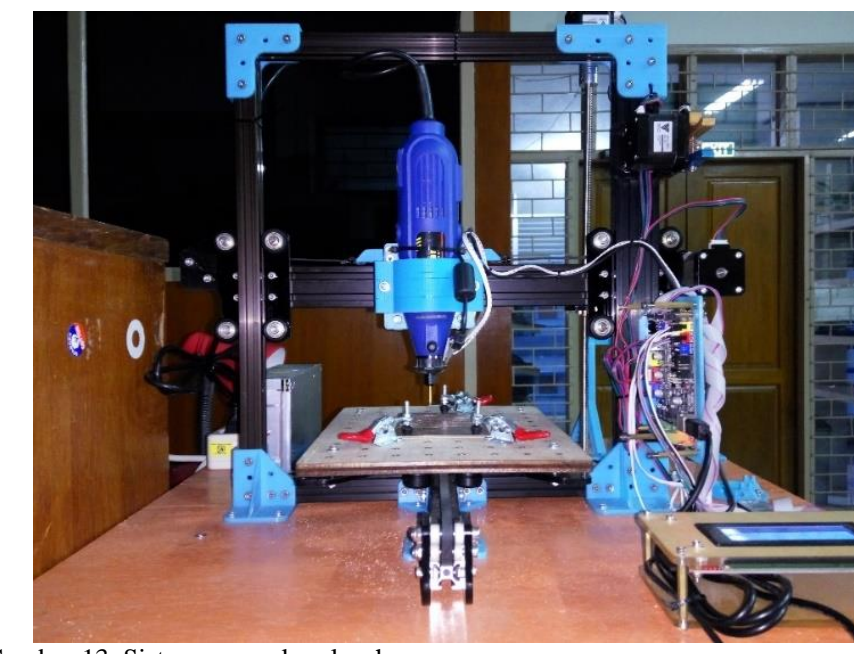

Gambar 13. Sistem secara keseluruhan

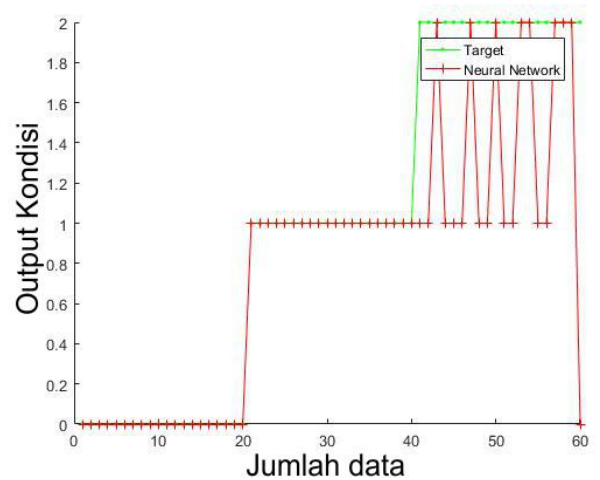

(a)

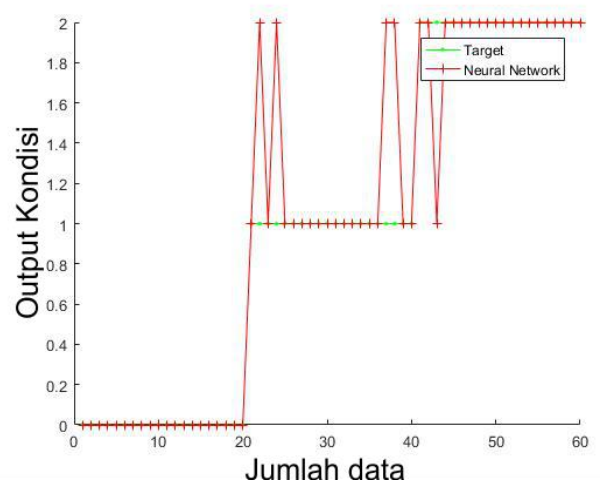

(b)

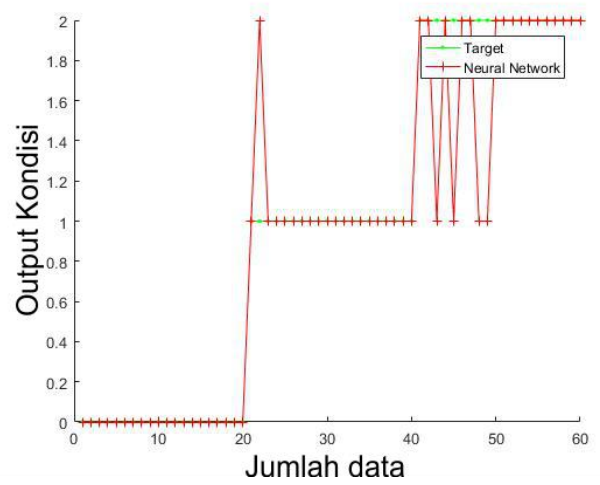

(c)

Gambar 14. Hasil pengujian keseluruhan dengan (a) satu kecepatan spindle (b) banyak kecepatan spindle (c) material PCB Fiber

Pada gambar 11 dapat dilihat adanya perbedaan antara target dan hasil Artificial Neural Network hanya terjadi pada
3 titik dari 35 data uji. Sehingga hasil pengujian ANN secara offline diperoleh keberhasilan $\frac{35-3}{35} \times 100 \% \approx 91,4 \%$. Hasil ini menjadi acuan untuk menerapkan nilai weight dan bias pada pada tahap testing di mikrokontroler agar dapat menjalankan pengujian secara keseluruhan dengan tingkat keberhasilan yang tinggi. Gambar 12 menunjukkan bahwa algoritma yang diterapkan pada Teensy 3.2 sudah sesuai dan siap untuk memproses input dari FFT secara langsung untuk pengujian sistem secara keseluruhan.

\section{Pengujian Secara Keseluruhan}

Sistem secara keseluruhan ditunjukkan pada gambar 13 . Pengujian sistem secara keseluruhan dilakukan dengan menerapkan algoritma ANN pada Teensy 3.2. Dari pengujian sistem ini didapat hasil bahwa dengan melakukan pembelajaran ANN menggunakan satu kecepatan spindle menghasilkan keberhasilan $80 \%$. Saat pembelajaran dilakukan dengan menambah data menjadi banyak kecepatan spindle maka keberhasilan meningkat menjadi 91,67\%. Begitu pula saat mengganti material yang dicetak menggunakan bahan jenis fiber, maka keberhasilan menjadi 91,67\% juga. Hal ini menunjukkan bahwa semakin banyak data pembelajaran ANN maka semakin akurat pula pengenalannya. Selain itu PCB dari bahan fiber memiliki tingkat kekerasan yang lebih tinggi sehingga sensor dapat memberikan perbedaan getaran yang signifikan.

\section{KESIMPULAN}

Pada penelitian ini telah dibuat suatu sistem pendeteksian kepatahan mata bor berdasarkan analisa getaran. Sensor yang digunakan untuk dapat mendeteksi getaran adalah MEMS accelerometer yang mempunyai kemampuan pengukuran sampai 3,6g. Pendeteksian kepatahan mata bor pada pencetak PCB dapat diamati menggunakan spektrum getaran. Untuk dapat mengenali kepatahan mata bor, perlu dilakukan pengolahan sinyal dengan menggunakan Fast Fourier Transform. Lebar spektrum frekuensi yang digunakan adalah $0-1000 \mathrm{~Hz}$. Pola spektrum frekuensi ini digunakan sebagai input Artificial Neural Network dengan 2 hidden layer untuk dapat mengenali kepatahan mata bor. Pemrosesan Fast Fourier Transform dan Artificial Neural Network dilakukan pada Teensy 3.2. Tingkat keberhasilan ANN pada pengujian offline sebesar $91,4 \%$ dan pada pengujian online sebesar $80 \%$. Dengan memperbanyak data pembelajaran ANN, keberhasilan pengujian dapat meningkat menjadi $91,67 \%$. Peningkatan keberhasilan juga dapat dicapai pada jenis PCB fiber dengan keberhasilan 91,67\%.

\section{DAFTAR PUSTAKA}

[1] S. -y. C. dan K.-H. Y. H. S. Cho, J.-h. Han, "A tool breakage detection system using load signals of spindle motors in CNC machines," in Eighth International Conference on Ubiquitous and Future Networks (ICUFN), 2016, pp. 160-163.

[2] C.-E. L. dan Y.-W. H. C.-R. Huang, M.-C. Lu, "Study of spindle vibration signals for tool breakage monitoring in micro-drilling," in 20119 th World Congress on Intelligent Control and Automation, 2011, pp. 1130-1134.

[3] A. Els. dan S. B. M. Ali, "Controlling the CNC machine using microcontroller to manufacture PCB," in 2016 Conference of Basic Sciences and Engineering Studies (SGCAC), 2016, pp. 116120.

[4] F. I. H. dan A. S. A. T. Purnomo, "Development of Interface and Coordination for Control Module CNC PCB Milling Machine," in 2015 International Symposium on Intelligent Signal Processing and Communication Systems (ISPACS), 2015, pp. 246-251. 
[5] D. C. dan F. Hariadi, "Speed Control of Spindle Motor in The Designing Control Module of Computer Numerical Control (CNC) PCB Milling Machines," Institut Teknologi Bandung.

[6] T. dan S. Muhammad Rivai, "Pengenalan Pola Sinyal Suara Kerusakan Motor Listrik menggunakan Neural Network," JAVA J. Electr. Electron. Eng., vol. 5, pp. 51-55, 2007.

[7] T. M. dan D. P. Muhammad Rivai, "Pengaruh Variasi Suhu
Periodik Terhadap Selektivitas Gas Semikonduktor," 2009.

[8] T. dan T. M. Muhammad Rivai, "Peningkatan Taraf Identifikasi Jenis Gas di Udara Terbuka menggunakan Transformasi Fourier dan Principal Component Analysis," KURSOR, vol. 6, pp. 103110, 2011. 